\title{
Operability analysis of spindle-motor hybrid electromechanical systems
}

\author{
K. O. Oliinyk ${ }^{1}$
}

Received: 21 March 2021 / Accepted: 24 May 2021

\begin{abstract}
Motor-spindles are belong to a special class of complex dynamic systems of natural and natural-anthropogenic origin, which can be realized both translational and rotational motion, and represent a variety of developing species. Such systems are used in metalworking complexes, lathes, milling, drilling, grinding, multi-purpose and other machines. In modern designs of spindle units rolling bearings, hydrostatic, hydrodynamic, gas-static (aerostatic), gas-dynamic (aerodynamic), magnetic bearings and their combinations (hybrids) are used, for example, gas-magnetic (gas-static bearings with a magnetic suspension that allows to provide rotational frequencies) up to 10-20 thousand rpm, and in drilling and milling and grinding up to 100-200 thousand rpm and above. With the further development of technology in the machine-building industry, motor-spindles began to appear, which are able to realize the movement of the feed by means of gears and couplings, using pneumatic systems. They are also able to realize the movement of in using hydraulic systems, using screw gears. The design concepts of hybrid and combined the motor spindles, received by results of structural anticipation on the basis of use of innovative synthesis methods of hybrid electromechanical systems are considered. Results of mechanical calculations of rigidity and electromagnetic calculations are presented in the article. On the ground of the calculation data the operability analysis of the electromechanical systems of motor spindles is made. To develop a morphological model, functional features were selected, which are systematized and divided into three groups in accordance with the modular principle.
\end{abstract}

Keywords: electromagnetic chromosome, hybrid electromechanical structure, combined electromechanical systems, spindle motor, innovative synthesis, multi-coordinate drilling-milling machine, main motion drive, carrier system.

\section{Introduction}

Modern electromechanical systems of Spindlemotor-type are the result of the most advanced scientific and technical achievements in such areas of technical science, as: Machine-tool Construction, Electromechanics, Materials Science, Electronic control systems, etc.

The main application field of the spindle-motor systems is turning spindle unit development for milling machines and the processing centers in a mass production.

Results of fundamental research received in recent years in the field of Genetic and Structural Electromechanics (development of bases of the theory of hybrid electromagnetic and electromechanical systems (EMsystems) [1-4] and development of technology of struc-

K. O. Oliinyk

katya-all@ukr.net

${ }^{1}$ Ministry of Infrastructure of Ukraine, Kyiv, Ukraine tural anticipation $[3,5])$, has opened the possibility of realization of essentially new methodological approach for statement and solution of problems in search design of any classes of EM-systems, including the hybrid and combined systems of a various functional area by the set criterion function.

In this article the main results of electromagnetic and mechanical calculations and the analysis of operability of new versions of competitive samples of the combined hybrid EM-systems of Spindle-motor-type, received by the results of directed genetic synthesis $[5,7]$ are stated.

\section{Exposition}

Based on the results of synthesis of new spindlemotors with linear and rotary motion from a created number of the hybrid and combined electromagnetic chromosomes $[5,7]$ there were selected two chromosomes, most fully satisfying the set criterion function. On their basis there were developed two constructive solutions of spindle-motors intended for operation in metalworking ma- 


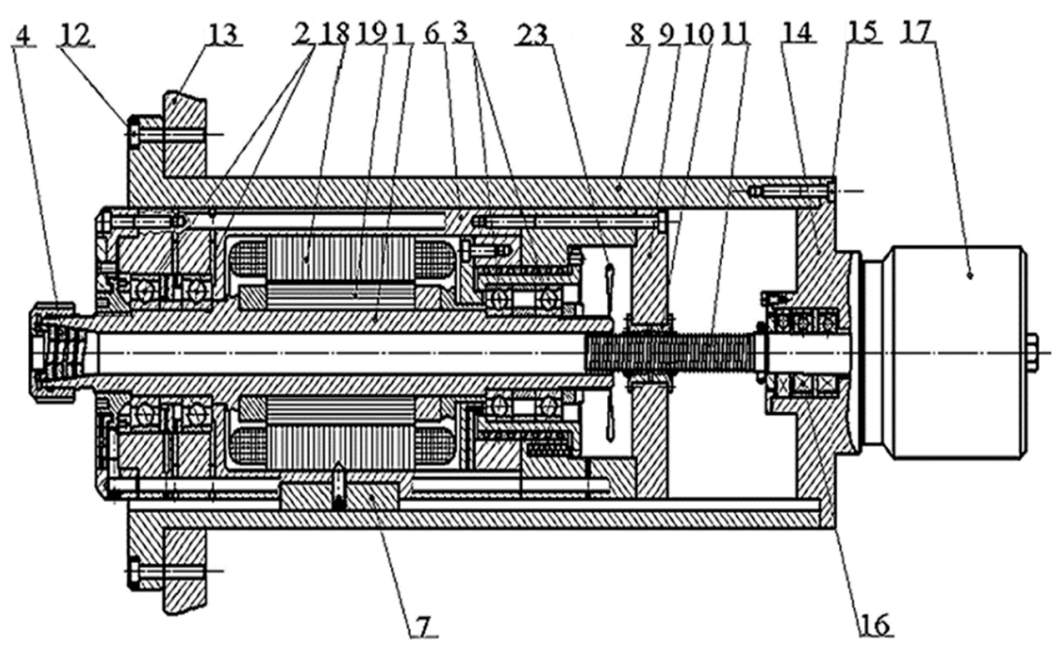

Fig. 1. Spindle-motor unit for machine tool station designed by results of genetic synthesis $[6,10]$

chinery of new generation $[8,9]$. One of constructive solutions of a new spindle-motor design is presented in Fig. 1 [10].

Its design consists of: 1 - spindle; 2, 3 - forward and back support; 4 - clamping chuck; 5 - cutting tool; 6 - movable sleeve; 7 - guide; 8 - guide slot; 9 - flange; 10 - screw nut; 11 - screw; 12 - fastening capscrews; 13 stationary part of machine tool; 14 - adapter flange; 15 screw connection; 16 - screw support; 17 - axis stepper motor; 18 - static stator; 19 - rotor; 23 - cooling fan.

In morphological models (Tables 1-3) from the work of V. Shinkarenko [11] the primary sources of the field and, in particular, the electromagnetic field are taken: CL - cylindrical; $\mathrm{CN}$ - conical; $\mathrm{TF}$ - toroidal flat; TC - toroidal cylindrical.

Also for the development a morphological set of models, we choose the functional features, which are divided into three groups in accordance with the modular principle [12]: the module of the drive of rotational main motion (table 1), the module of the drive of translational motion (feed) (table 2), mechanism (table 3).

To develop a morphological model, we choose the functional features, which are divided into three groups in accordance with the modular principle:

1. The module of the drive of rotary main movement.

2. The module of the drive of translational movement (feeds).

3. Clamping mechanism module.

For the first module we choose signs:

1. Source of energy.

2. Primary field source (PFS).

3. Number of spindles.

4. Type of spindle supports.

5. Supports of radial fixing of a spindle.

6. Support of axial fixing of a spindle.

7. Communication between spindles.

8. The connection of the spindle with the PFS

9. Geometric axis of the spindle.
10. Relative location of spindles.

11. Execution of the case of the spindle module.

For another module:

12. Source of energy.

13. PFS.

14. Type of motion transducer.

15. Location of guides.

16. Execution of guides.

17. Type of clamping chuck on the transducer of movement and force.

18. The base surface of the chuck for connection to the spindle.

19. Power source in the drive clamp-unclamp.

20. PFS

21. Type of energy (force) converter.

After developing a morphological model, proceed to the synthesis of variants. The number of options can be determined by astronomical numbers, because each of the characteristics (signs) has different options (alternatives). The set of variants of the morphological model allows to determine the full number of solutions.

Thus, the proposed model gives the total number of spindle assemblies and spindle-motor, among which there are many still unknown:

$$
N_{U B}=N_{U} \cdot N_{3} \cdot N_{\Pi}=680882825600
$$

Morphological models allow to systematize a fairly large amount of knowledge about morphology in a compact form, make it possible to formalize the process of ordering many of the options placed in the model. The quality of the morphological model largely determines the final result of the search for a solution to the problem [13].

The development of morphological models is the initial stage of morphological research-morphological analysis, the purpose of which is the classification of the studied object or set of objects, followed by the transition to morphological synthesis [14]. 
Table 1. Morphological model of structural diagrams of the rotary motion drive module

\begin{tabular}{|c|c|c|c|c|c|}
\hline \multirow{3}{*}{ 1. Energy source } & \multirow{3}{*}{$\begin{array}{l}\text { 2. Primary } \\
\text { field source } \\
\text { (PFS) }\end{array}$} & \multicolumn{4}{|c|}{ Spindle (rotor) } \\
\hline & & \multicolumn{4}{|c|}{ Supports } \\
\hline & & 3. Number & 4. View & 5.Radial fixation & 6. Axial fixation \\
\hline 1.1.Electrics & 2.1. CL & 3.1 .1 & 4.1. Rolling & 5.1.One radial & 6.1.One axial \\
\hline 1.2.Liquid & 2.2. CN & 3.2 .2 & 4.2. Liquid & 5.2. Two radial & 6.2. Two axial \\
\hline 1.3.Air & 2.3.TF & $3.3 .>2$ & 4.3. Air (Gas) & 5.3. Three radial & $\begin{array}{l}\text { 6.3. One radial } \\
\text { thrust }\end{array}$ \\
\hline 1.4.Combination & 2.4.TC & & 4.4. Magnetic & $\begin{array}{l}\text { 5.4. One radially- } \\
\text { persistent }\end{array}$ & $\begin{array}{l}\text { 6.4. Two radial- } \\
\text { thrust }\end{array}$ \\
\hline & & & 4.5. Combined & & 6.5. None \\
\hline \multicolumn{2}{|c|}{ 7. Between the spindles } & 8. PFS & 9. Geometric axis & 10.1. In parallel & 11.1.Flanges \\
\hline \multicolumn{2}{|c|}{ 7.1. None } & $\begin{array}{l}\text { 8.1. Coaxially } \\
\text { through the } \\
\text { coupling }\end{array}$ & 9.1. Horizontal & 10.2. Perpendicular & 11.2. On the paws \\
\hline \multicolumn{2}{|c|}{ 7.2. Electro-magnetic field } & $\begin{array}{l}\text { 8.2. Inside } \\
\text { (built-in) }\end{array}$ & 9.2. Vertical & 10.3. At an angle & 11.3. In the bracket \\
\hline \multirow{2}{*}{\multicolumn{2}{|c|}{ 7.3. Mechanical }} & $\begin{array}{l}\text { 8.3.Through } \\
\text { mechanical } \\
\text { transmission }\end{array}$ & 9.3. Inclined & & $\begin{array}{l}\text { 11.4. With one } \\
\text { enclosing stator }\end{array}$ \\
\hline & & & 9.4.Horizontally-vertical & & \\
\hline
\end{tabular}

Table 2. Morphological model of structural diagrams of the feed module (translational drive)

\begin{tabular}{|c|c|c|c|c|}
\hline \multirow{2}{*}{ 12. Source of energy } & 13. PFS & $\begin{array}{c}\text { 14. Type of motion } \\
\text { transducer }\end{array}$ & \multicolumn{2}{|c|}{ Guides } \\
\cline { 3 - 5 } & 13.1.CL & $\begin{array}{c}\text { 14.1. Screwing steam } \\
\text { sliding }\end{array}$ & $\begin{array}{c}\text { 15.1. Parallel to the } \\
\text { same plane as the } \\
\text { spindle axis }\end{array}$ & 16.1. Rolling on balls \\
\hline 1.1. Electricity & $\begin{array}{c}\text { 13.2. flat in one } \\
\text { direction }\end{array}$ & $\begin{array}{c}\text { 14.2. Rolling screw pair } \\
\text { 1.2. Liquid }\end{array}$ & $\begin{array}{c}\text { 15.2. Coaxially behind } \\
\text { the spindle }\end{array}$ & 16.2. Rolling on rollers \\
\hline 1.3. Air & directions & $\begin{array}{c}\text { 14.3. Gear-rail } \\
\text { transmission }\end{array}$ & $\begin{array}{c}\text { 15.3. Coaxially inside } \\
\text { the spindle }\end{array}$ & 16.3.Sliding on the bars \\
\hline 1.4. Combination & 14.4. None & $\begin{array}{c}\text { 15.4.Made in another } \\
\text { plane }\end{array}$ & $\begin{array}{c}\text { 16.4.Sliding in grooves } \\
\text { (or holes) }\end{array}$ \\
\hline
\end{tabular}

Table 3. Morphological model of constructive diagrams of the module of the blocking mechanism

\begin{tabular}{|c|c|c|c|c|}
\hline \multicolumn{2}{|c|}{ Clamping chuck } & \multicolumn{2}{c|}{ Clamp drive } \\
\hline 17. Type & 18. Base surface & 19. Source of energy & 20. PFS & $\begin{array}{c}\text { 21. Type of energy conversion } \\
\text { (force) }\end{array}$ \\
\hline 17.1.Elastic & 18.1. Conical & 19.1. Electrical & 20.1. CL & 21.1. Screw sliding \\
\hline 17.2.Spiral & 18.2. Two conical & $\begin{array}{c}\text { 19.2. Biological (by } \\
\text { hand) }\end{array}$ & 20.2. PL & 21.2. Ball-screw pair \\
\hline 17.3.Wedge & 18.3. Conical and butt & 19.3.Hydraulic & & 21.3. Gear transmission \\
\hline 17.4.Lever & 18.4. Conical and cylindrical & 19.4. Air & & \\
\hline
\end{tabular}




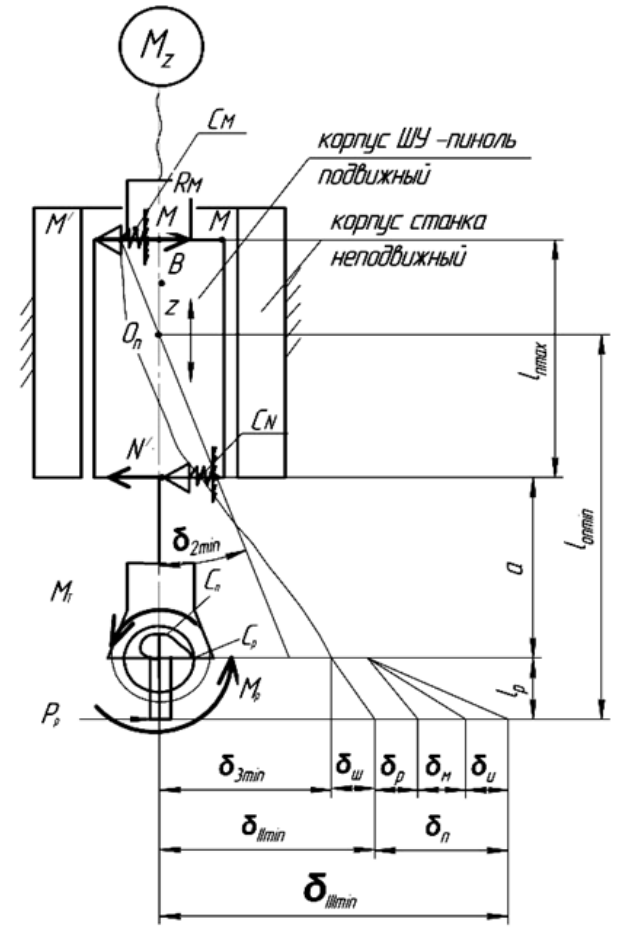

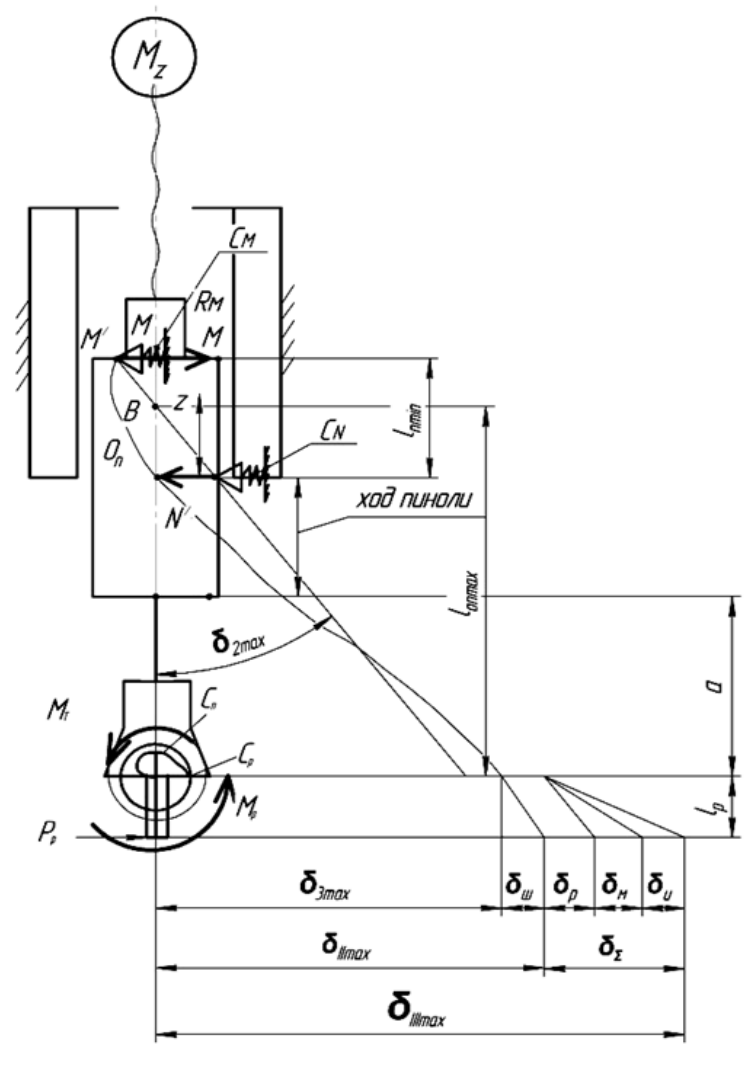

$b$

Fig. 2. The analytical model of influence of design parameters on static stiffness in a spindle-movable sleeve-tool system with due consideration of compliance of spindle bearing section and movable sleeve during milling cutter displacements: $a$ ) minimum, $b$ ) maximum

For the first time, an integrated model for schematic-many-parametric synthesis of spindle assemblies using different energy sources and converters in the form of a morphological set of three morphological models of constructive schemes of modules: main motion drive; feed drive (longitudinal motion); clamping mechanism.

To check operability of spindle-motor system the stiffness analysis of spindle-movable sleeve-tool taking into account a compliance of spindle bearing section, chuck and movable sleeve was made.

The analytical model for definition of influence of design parameters on static stiffness [15] in a spindlemovable sleeve-tool system is presented in fig. 2. Part positioning in a fixation point in the chuck is considered as the hypothetical elastic and frictional hinge and depends on type of the chuck and a way of tool retention.

Fig. 3 represents the milling cutte displacement vs movable sleeve reach diagrams [16].

Testing of the synthesized and manufactured amateur motor-spindle (Fig. 4) for rigidity [17], which was carried out in accordance with the recommendations of
GOST 370-93 "Vertically vertical drilling. Norm of accuracy and rigidity" and GOST 9726-89 "Vertical milling machines with a cross table. Terminology. Basic dimensions. Standards of accuracy and rigidity", showed its efficiency and competitiveness.

These dependency diagrams give the possibility to conclude, that for increasing the static stiffness of the automatically operated spindle-motor system by the means of design parameters it is necessary:

a) to increase stiffness of the chuck tool system by the means of clamping chuck with double clip application [18];

b) to increase stiffness by the means of movable sleeve base increasing [19];

c) to reduce a gap, to decrease the undulation and to use roller ways instead of slide ways.

At the present moment the production of the spindle-motor prototype, corresponding to this constructive decision, is realizing.

The other constructive solution of spindle-motor system, developed on the basis of the synthesized hybrid EM-structure features realization of linear motion by means of the linear electrical motor. 


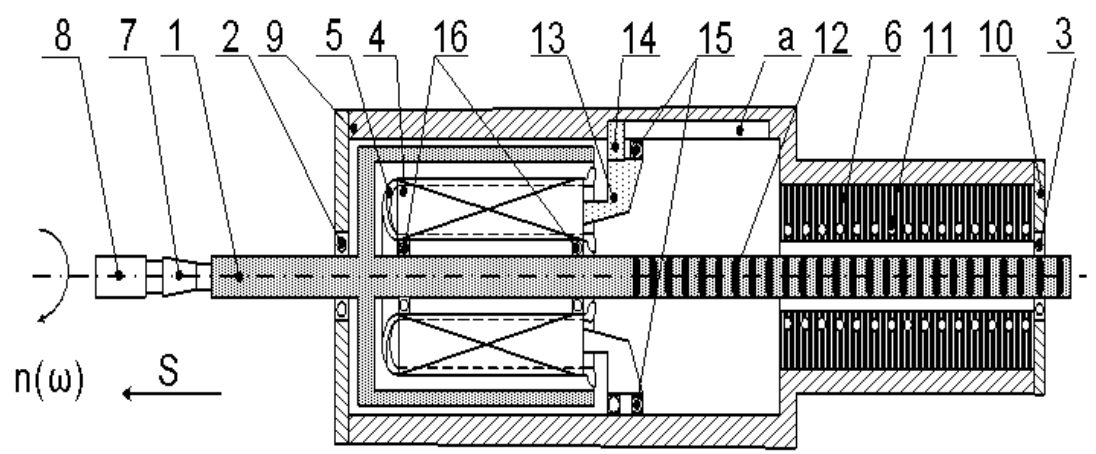

Fig. 4. The design of direct drive spindle-motor

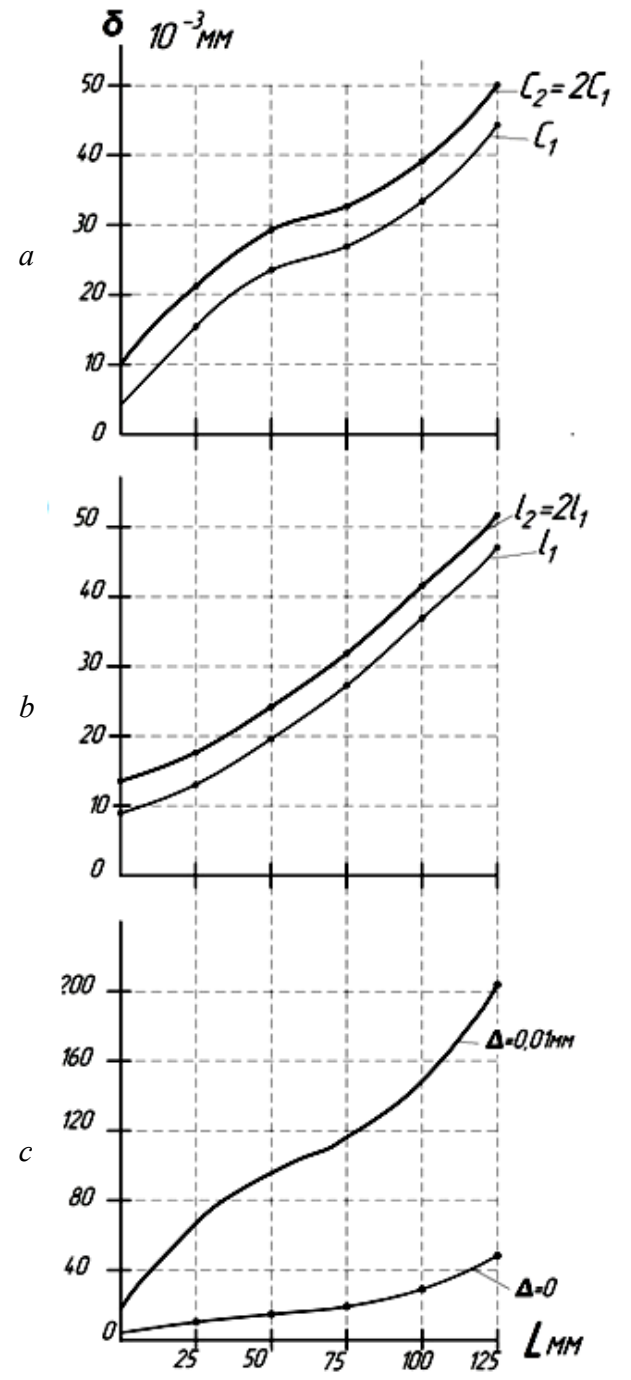

Fig. 3. Dependence diagrams of the milling cutter displacement at the place of force $\mathrm{P}$ against movable sleeve reach: $a$ ) in case of two stiffnesses of the chuck-tool system; $b$ ) in case of movable sleeve base increasing; $c$ ) in case of two end plays
Such spindle - motor unit (Fig. 4) [20] consists of:

1 - spindle; 2,3 - bearings; 4 - stator of rotating movement electrical machine; 5 - stator winding; 6 guide slot; 7 - inner rotor of rotating movement electrical machine; 8 - outer rotor of rotating movement electrical machine; 9 - movable sleeve; 10 - clamping chuck; 11 cutting tool; 12 - case; 13 - adapter flange; 14 - linear inductor; 15 - winding of linear inductor; 16 - mover of linear inductor with permanent magnets; 17 - supporting arm; 18 - guide; 19 - Bearings of linear motion guide.

One of the features of the synthesized hybrid structure of spindle-motor (fig. 4) is that, the distributed stator winding of rotating electric machine is performed by Ushaped sections forming dual active surface. The movable sleeve is performed hollow as two mechanically connected cylinder surfaces, where the external and internal rotors are mounted. The external and internal rotor windings are designed with cupper sputtering [21].

To prove the operability of this electromechanical converter the electromagnetic calculations of electrical machines of the main and linear movements were made using analytical methods and the finite-elements method in the program environment of COMSOL Multiphysics 3.5a [22].

The following parameters of serial spindle-motors of average power were taken as the initial data of calculation:

$$
\begin{aligned}
& \text { — output power: } P_{2}=35 \mathrm{~kW} \\
& \text { — } \text { rotation speed: } n=10000 \mathrm{rpm} ; \\
& \text { — } \text { spindle - motor diameter: } D_{1}=0,2 \mathrm{~m} ; \\
& \text { — active length: } L_{1}=0,315 \mathrm{~m} ; \\
& \text { — number of phases: } m=3 ; \\
& \text { — } \text { voltage level: } U=480 \mathrm{~V}
\end{aligned}
$$

There were calculated and constructed the running characteristics, as well as currents and active capacities dependences on loading (fig. $5 a, b$ ) for the electrical machine 


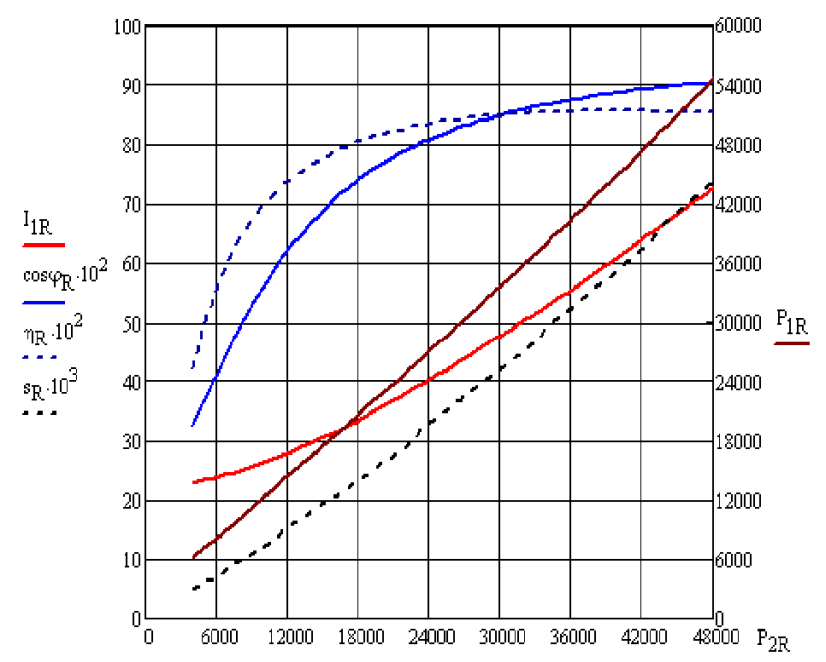

$a$

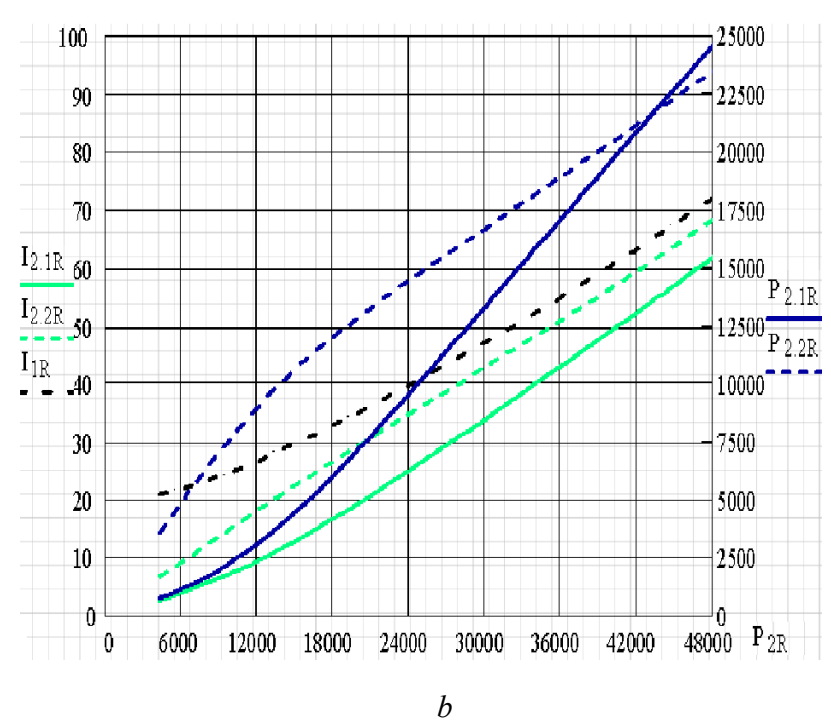

$b$

Fig. 5. The estimated characteristics of the main movement electrical machine of spindle-motor: $a$ ) running characteristics, $b$ ) currents and active capacities dependences on loading

of the main movement. The electromagnetic fields mathematical modelling results are presented at the fig. 6. [23].

It is also planned to make the experimental prototype of hybrid spindle-motor of this design (fig. 4.).

\section{Conclusion}

To make the operability analysis of the developed constructive solutions of new spindle-motor systems the mechanical and electromagnetic calculations confirming operability of the synthesized designs were executed.
To increase the static stiffness of the automatically operated spindle-motor system (fig. 1) it is necessary to increase stiffness of the chuck-tool system by the means of clamping chuck with double clip application, to increase stiffness by the means of movable sleeve base increasing, to reduce a gap, as well as to decrease the undulation and to use roller ways instead of slide ways.

To reduce the iron loss of the automatically operated spindle-motor system (fig. 4) it is necessary to make the optimization of the slot configuration of an external stator active surface of the main movement electrical machine.

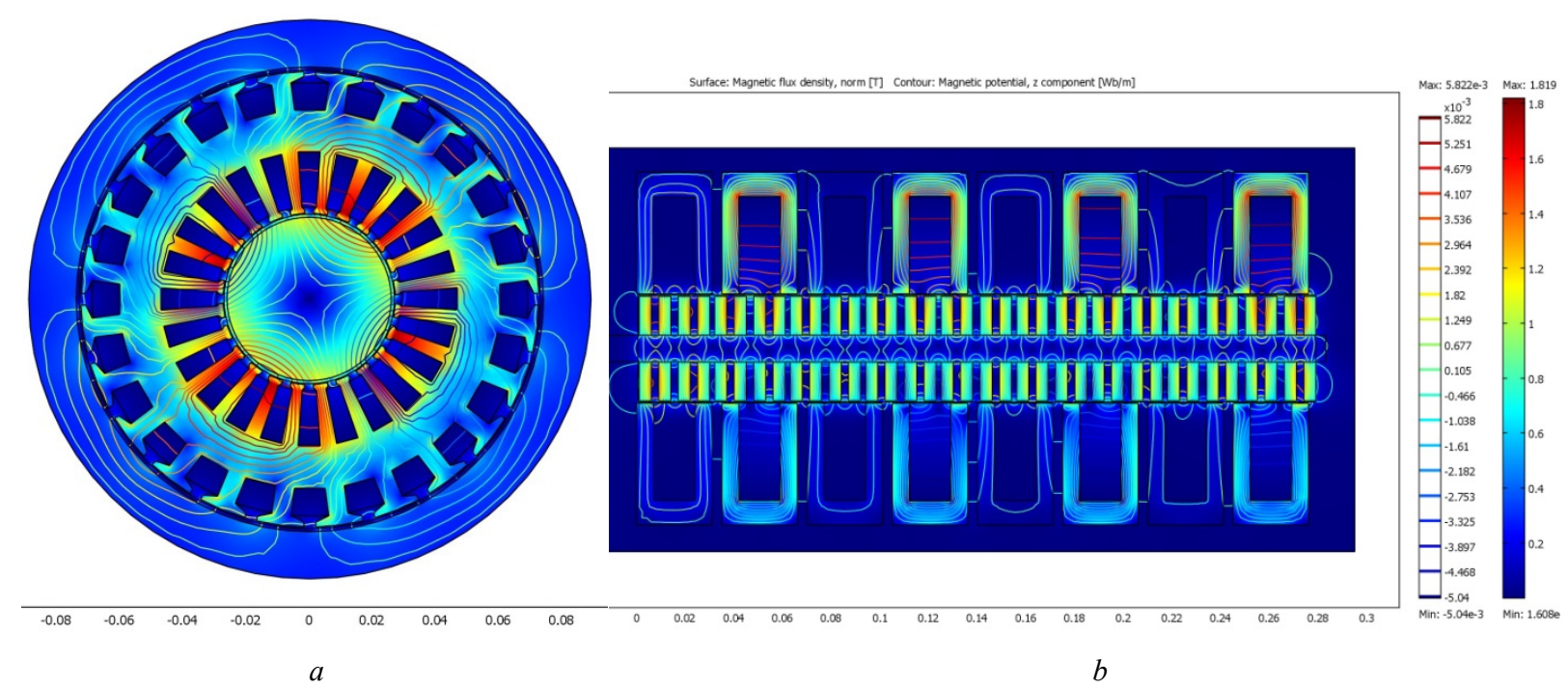

Fig. 6. Electromagnetic fields calculations: $a$ ) electrical machine of the main movement; $b$ ) electrical machine of linear movement 


\section{References}

[1] V. Shinkarenko, Bases of Electromechanical Systems Evolution Theory. Kyiv, Ukraine: Naukova dumka, 2002.

[2] V.F.Shinkarenko, I.V. Gaidaienko and O.L. Miroshnik, "Structural foresight and streamlined synthesis models of hybrid electromechanical objects at intrageneric level", Collection of scientific works "Electrical machines theory and design issues", Ulianovsk: UlGTU, pp. 105-112, 2010.

[3] V. Shinkarenko, Iu. Gaidaienko and Ahmad N. Al-Husban, "Genetic Programs of Structural Evolution of Hybrid Electromechanical Objects", International journal of Engineering \& Technology. Vol 2, No 1, pp. 44-49, 2013. https://doi.org/10.14419/ijet.v2i1.571

[4] I. Gaidaienko, V. Shynkarenko, "Principles of structural organization and genetic creation models of hybrid electromechanical systems”, in Proc.11th Anniversary International scientific Conference Unitech'11, Gabrovo, Bulgaria, 2011, pp. 79-84.

[5] I.V. Gaidaienko, A.S. Kovtun and R. Atanasov, "Structural foresight and directed synthesis of new structures of 'spindle-motor'-type systems", in Proc. Proceedings of the International scientific and technical conference of young researchers Ph.D-students and students. "Modern problems of electric power engineering and automatics", Kyiv, 2011, pp. 241-244.

[6] Hybrid electromechanical system of "spindle-motor"-type, in Proceedings of the International scientific and technical conference of young researchers Ph.D-students and students. "Modern problems of electric power engineering and automatics", Kyiv: Polytechnika, 2012. pp. 255-257.

[7] I.V. Gaidaienko, A.S. Kovtun and V.F. Shynkarenko, "Searching design of electromechanical modules of the 'spindle-motor'type using the technology of structural prediction”, in Proc. The efficiency increase problems of electromechanical energy convertersion in electric-power systems, Sevastopol, 2012, pp. 110-113.

[8] K. Oliynyk, I. Gaidaienko and Y. Kuznietsov, "The spindle-motors with new functionality for metal-cutting machines", in Proc. Ternopil Ivan Pul'uj National Technical University, Ternopil, 2012. Vol. II MATERIALS SCIENCE AND MACHINE ENGINEERING, p. 55.

[9] K. Oliynyk, I. Gaidaienko and Y. Kuznietsov, "The automatic spindle-motors for metal-cutting machines of new generation", in Proc. Relevant objectives of modern technologies, Ternopil, 2012, pp. 114-115.

[10] Y.M. Kuznietsov et al., "Spindle unit for metal-cutting machine", No. 65488, Claim for invention No. u201105576, 04.05.2011 In.Cl. B23B 47/00, B23B 19/00, 04.05.2012.

[11] V.F. Shinkarenko, Osnovi teoriï evolyuciï elektromekhanichnih system, Kyiv: Naukova dumka, 2002.

[12] J. Kuzniecow, K. Olejnik and A. Stepanenko, "Modulowe podejscie do projektowania frezarek stolowych sterowanych numerycznie", Kwartalnik 19 zeszyty naukowe politechniki Rzeszowskiej (Mechanika), No. 84, pp. 51-60, 2012.

[13] V. Shinkarenko et al., "The operability analysis of spindle-motor hybrid electromechanical systems", in Proc. Unitech'13, Gabrovo, Bulgaria, 2013, Vol. III, pp. 268-272.

[14] Yu.N. Kuznecov et al., "Morfologicheskij sintez stankov i ih mekhanizmov”, Kyiv: OOO “Gnozis”, 2012.

[15] V.E. Push, Devolopment of metal-cutting machines, Moscow, Russia: Mashinostroenie, 1977.

[16] Z.M. Levina, D. N. Reshetov, Machines contact stiffness, Moscow, Russia: Mashinostroenie, 1971.

[17] Y.M. Kuzniecov et al., "Zhorstkistni harakteristiki samodiyuchogo motor-shpindelya dlya verstativ z CHPK, Mashinostroenie i tekhnosfera XXI veka”, Sbornik trudov HKH mezhdunarodnoj nauchno-tekhnicheskoj konferencii, Sevastopol, T2, Doneck: DonNTU, 2013, pp. 44-52.

[18] Y.N. Kuznietsov et al., "Collet chucks with double clip: theory and practice”, Monograph, K.:JSC "GNOZIS”, 2013.

[19] Y.N. Kuznietsov et al., "Grip sockets”: Monograph, K.:JSC “GNOZIS”, 2012.

[20] V.S. Mogylnikov and O.M. Oleynikov, "Theory, technology and modes of operations of asynchronous engines with a doublelayer rotor", Monograph, 2-nd ed., Sebastopol: SevNTU, 2008.

[21] Y.M. Kuznietsov et al., "Spindle unit for metal-cutting machine", No. 82880, Claim for invention No. u201211168 In.Cl. H02 K35/00, stated 26.09.2012.

[22] I. Gaidaienko, "Hybrid electromechanical system of 'spindle-motor'-type for metal-cutting machines of new generation", in Proc. Electromechanical and energy systems, modeling and optimization methods, Kremenchuk, KrNU, 2013, pp. $279-280$.

[23] K. Oliinyk, The synthetis of a spindle unit based on a motor-spindle using a sistemic morphological approach, Transactions of Kremenchuk Mykhailo Ostrohradskyi National University, Kremenchuk: KRNU, issue 5-6 (124-125), pp. 110-115, 2020. https://doi.org/10.30929/1995-0519.2020.5-6.133-138. 


\title{
Анализ использовния электромеханических систем типа мотор-шпиндель
}

\author{
К. А. Олейник
}

Аннотация. Мотор-ипиндели принадлежат к особому классу сложных динамических систем природного и природноантропогенного происхождения, которые могут реализовывать как поступательное, так и вращательное движение, и представляют различные виды, которые развиваются. Такие системы применяются в металлообрабатывающих комплексах, токарных, фрезерных, сверлильных, илифовальных, многоцелевых и других станках. В современных конструкииях ипиндельных агрегатов используются подшипники качения, гидростатические, гидродинамические, газостатических (аэростатические), газодинамические (аэродинамические), магнитные подшипники и их комбинации (гибриды), например, газомагнитни (газостатических подшипники с магнитная подвеска, позволяющая обеспечивать частоты вращения) до 10-20 тыс. об/мин, а при сверлении и фрезеровании и шллфовании до 100-200 тыс. об/мин и выше. С дальнейшим развитием технологий в машиностроительной промышленности стали появляться мотор-ипинделя, которые способны реализовывать движение подачи с помощью шестерен и мурт, используя пневматические системы.

Они также могут реализовывать движение при использовании гидравлических систем, используя винтовые шестерни. Рассмотрены конструктивные концепции гибридных и комбинированных мотор-ипинделей, полученные по результатам предсказания конструкции на основе использования инновационных методов синтеза гибридных электромеханических систем. В статье представлены результаты механических расчетов жесткости и электромагнитных расчетов. На основании расчетных данных проведен анализ работоспособности электромеханических систем шиинделей двигателя. Для разработки морфологической модели был выбран функциональные признаки, которые систематизированы и разделены на три группы в соответствии с модульного принципа.

Ключевые слова: электромагнитная хромосома, гибридная электромеханическая структура, комбинированные электромеханические системы, ипиндельный узел, инновационный синтез, многокоординатного сверлильно-фрезерный станок, главный привод, несущая система, мотор-ипиндель, электромеханический привод, системно-морфологический подход, синтезированный привод главного движения.

\section{Аналіз використання електромеханічних систем типу мотор-шпиндель}

\section{К. О. Олійник}

Анотація. Мотор-шпинделі належать до особливого класу складних динамічних систем природного та природноантропогенного походження, які можуть реалізовувати як поступальний, так $і$ обертальний рух, $і$ представляють різноманітні види, щңо розвиваються. Такі системи застосовуються в металообробних комплексах, токарних, фрезерних, свердлильних, шліфувальних, багатоцільових та інших верстатах. У сучасних конструкціях шпиндельних агрегатів використовуються підчипники кочення, гідростатичні, гідродинамічні, газостатичні (аеростатичні), газодинамічні (аеродинамічні), магнітні підшипники та їх комбіначії (гібриди), наприклад, газомагнітні (газостатичні підшипники з магнітна підвіска, щзо дозволяс забезпечувати частоти обертання) до 10-20 тис. об/хв, а при свердлінні та фрезеруванні та шліфуванні до 100-200 тис. об/хв і вище. 3 подальшим розвитком технологій у машинобудівній промисловості стали з'являтися моторшпинделі, які здатні реалізовувати рух подачі за допомогою шестерень і муфт, використовуючи пневматичні системи. Вони також можуть реалізовувати рух при використанні гідравлічних систем, використовуючи гвинтові шестерні. Розглянуто конструктивні конщепиї гібридних та комбінованих моторних шпинделів, отримані за результатали передбачення конструкиії на основі використання інноваційних методів синтезу гібридних електромеханічних систем. У статті представлені результати механічних розрахунків жорсткості та електромагнітних розрахунків. На підставі розрахункових даних проведено аналіз прачездатності електромеханічних систем шпинделів двигуна. Для розробки морфологічноі моделі було обрано функиіональні ознаки, які систематизовано та розділено на три групи відповідно до модульного принüuny.

Ключові слова: електромагнітна хромосома, гібридна електромеханічна структура, комбіновані електромеханічні системи, ипиндельний вузол, інновачійний синтез, багатокоординатний свердлильно-фрезерний верстат, головний привід, несуча система, мотор-ипиндель, електромеханічний привод, системно-морфологічний підхід, синтезований привод головного pyxy. 